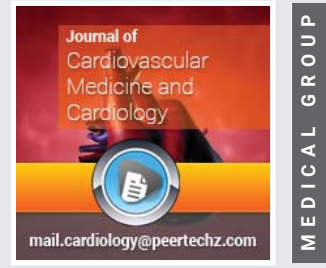

\title{
FMTVDM-Finally Opens the Doorway from Qualitative to Quantitative Measurement and Treatment of Heart Disease
}

\author{
Richard M Fleming* and Matthew R Fleming
}

Diagnostic determination of coronary artery disease has primarily relied upon qualitative image interpretation and tests of minimal measureable value. The introduction of the first measureable test dates back to the late 1890s following its presentation by Willem Einthoven at a Dutch Medical Association Conference in 1893-the electrocardiogram.

While the electrocardiogram provides millimeter changes on paper-these changes do not translate into measureable myocardial consequence. The same is true for blood tests, which are frequently obtained during acute coronary syndrome evaluations-including troponin (more than one type currently in use), Creatine Kinase (CK-MB) and a plethora of other blood tests-in an effort to determine if the patient is experiencing a Myocardial Infarction (MI).

Other efforts at quantification include echocardiographywhere ultrasound is used to measure blood flow velocities through the inner chambers of the heart, as well as dimensions of those chambers and their thickness. The end result is a measurement that is then translated into outcomes defined as mild, moderate and severe-hardly the terms of quantification.

The same outcome has been seen for the use of Myocardial Perfusion Imaging (MPI)-the utilization of nuclear isotopes to qualitatively assess perfusion of the heart. There have been several recent attempts to report such MPI results in terms of quantification however a review of publications addressing the use of Standard Uptake Values (SUV), show SUV to be-at best-a semi-quantitative approach [1-14].

While more accepted as providing a quantitative method for measuring the extent of coronary artery disease, coronary arteriography-frequently used to provide information about percent Diameter Stenosis (\%DS) - only finds coronary artery disease once there has been sufficient build up of inflammatory material within the walls of the coronary arteries as to finally intrude upon the coronary artery-lumen producing identifiable narrowing $[15,16]$. Independently, there is also the additional problem associated with reader interpretation and error $[17,18]$.

Consequently a series of investigative studies over the last twenty-years-examining earlier attempts at quantificationresulted in the development of the first quantitative method providing accurate, consistent and reproducible coronary blood flow measurements [19-43]. This method does not require the introduction of new equipment, drugs, or isotopes. It does however require a patent licensure to use. Full details of the science behind FMTVDM will soon be released in a medical textbook, which will also be used in the curriculum of U.S. training programs [44]. FMTVDM has become the doorway through which we will now be able to walk from the world of qualitative to quantitative medicine.

\section{Acknowledgement}

FMTVDM is issued to first author. No other COIs to report.

\section{References}

1. Fleming RM, Fleming MR, McKusick A, Chaudhuri TK, Dooley WC, et al. (2018) FMTVDMC(D stress-first/stress-only imaging is here! But first we need to clarify the use of what (1) Stress, (2) rest, (3) redistribution and (4) quantification, really mean. J Nucl Med Radiat Ther 9. Link: https://bit.ly/2JSBaiW

2. Fleming RM, Fleming MR, McKusick A, Chaudhuri TK (2018) Semiquantification limitations: FMTVDM@® demonstrates quantified tumor response to treatment with both regional blood flow and metabolic changes. J Nucl Med 59: 1643-1644. Link: https://bit.ly/34zMVVa 
3. Fleming RM, Fleming MR, McKusick A, Chaudhuri TK (2018) FMTVDM@® Nuclear Imaging Artificial (AI) Intelligence but first we need to clarify the use of (1) Stress, (2) Rest, (3) Redistribution and (4) Quantification. Biomed J Sci and Tech Res 7: 1-4. Link: https://bit.ly/3c8xsOd

4. Fleming RM, Fleming MR, McKusick A, Chaudhuri TK (2018) Virtua quantification is not True quantification. FMTVDM-TFM@® Provides True quantification for SPECT and PET. Arch Med 10: 1-3. Link: https://bit.ly/3bcwpwV

5. Fleming RM (2018) FMTVDM@® Provides the First True SPECT and PET Quantification and Not Virtual Guesstimation Produced by SUV and Extraction Fraction, Yielding First Accurate Theranostic Method. J Nucl Med Radiat Ther 9: e118. Link: https://bit.ly/3edi6Kb

6. Fleming RM, Fleming MR, Dooley WC, McKusick A, Chaudhuri T (2018) FMTVDM@(D Provides the First Nuclear Quantitative Method for Nuclear Cardiology and Introduces a New Era for Nuclear Cardiology. J Nucl Card 25 1453.

7. Fleming RM, Fleming MR, Chaudhuri TK, McKusick A (2019) FMTVDM@® Provides the First Patented Quantification of Myocardial Perfusion Imaging (MPI) Yielding Theranostic Benefit for Individuals with Suspected Coronary Artery Disease (CAD). Biomed J Sci Tech Res 13. Link: https://bit.ly/3ccVOqj

8. Fleming RM, Fleming MR, Chaudhuri TK, Andrew M (2019) FMTVDM provides first patented Quantitative Method to accurately Measure both Heart Disease and Breast Cancer on the "Health-Spectrum". J Cardiovasc Med Cardiol 6: 019-020. Link: https://bit.ly/3eiTC2r

9. Fleming RM, Fleming MR (2019) The Importance of Thinking about and Quantifying Disease like Cancer and Heart Disease on a "Health-Spectrum" Continuum. J Compr Cancer Rep 3: 1-3. Link: https://bit.ly/2ViENnM

10. Fleming RM, Fleming MR, Chaudhuri TK (2019) True Al Implementation Through FMTVDM Proprietary Equations and QCA. Biomed J Sci Tech Res 20: 15154-15160. Link: https://bit.ly/2y1GCxj

11. Fleming RM, Fleming MR, Chaudhuri TK, McKusick A, Dooley WC (2019) Nuclear Imaging: Physician Confusion Over True Quantification and Isotope Redistribution. J Clin Cases Rep 3: 32-42. Link: https://bit.ly/2yShF82

12. Fleming RM, Fleming MR, Chaudhuri TK (2019) The Need to Actually Measure What We're Talking about before We Put it All Together. Int J Nuclear Med Radioactive Subs 2: 000114

13. Sheikh A (2018) Evolution of Quantification in Clinical Nuclear Medicine: A Brief Overview of Salient Uses and Upcoming Trends. J Nucl Med Radiat Ther 9: 375. Link: https://bit.ly/2VjC2m1

14. Fleming RM, Fleming MR, Dooley WC, Chaudhuri TK (2020) Invited Editorial. The Importance of Differentiating Between Qualitative, Semi-Quantitative and Quantitative Imaging - Close Only Counts in Horseshoes. Eur J Nucl Med Mol Imaging 47: 753-755. Link: https://bit.ly/2RuaPMx

15. Fleming RM (2000) Shortcomings of coronary angiography. Letter to the Editor. Cleve Clin J Med 67: 450-451. Link: https://bit.ly/34t6jmw

16. Fleming RM (2001) Coronary Artery Disease is More than Just Coronary Lumen Disease. Amer J Card 88: 599-600. Link: https://bit.ly/2ySGlb1

17. Fleming RM, Kirkeeide RL, Smalling RW, Gould KL (1991) Patterns in Visua Interpretation of Coronary Arteriograms as Detected by Quantitative Coronary Arteriography. J Am Coll Cardiol 18: 945-951. Link: https://bit.ly/3efiyHJ

18. Fleming RM, Fleming DM, Gaede R (1996) Teaching Physicians and Health Care Providers to Accurately Read Coronary Arteriograms. Angiology 47: 349359. Link: https://bit.ly/3caEm5H

19. The Fleming Method for Tissue and Vascular Differentiation and Metabolism (FMTVDM) using same state single or sequential quantification comparisons. Patent Number 9566037
20. Fleming RM, Harrington GM, Baqir R, Jay S, Challapalli S, et al. (2009) The Evolution of Nuclear Cardiology takes Us Back to the Beginning to Develop Today's "New Standard of Care" for Cardiac Imaging: How quantifying regional radioactive counts at five and 60 minutes post-stress unmasks hidden ischemia. Methodist Debakey Cardiovasc J 5: 42-48. Link: https://bit.ly/34umwrS

21. (2009) Quantifying Regional Radioactive Counts at 5 and 60 Minutes PostStress Unmasks Hidden Ischemia. Methodist DeBakey Cardiovascular Journal (MDCVJ) 5: 42-48.

22. Fleming RM, Harrington GM (2010) FHRWW stress SPECT protocol reduces radioactive dosage and increases ischemia detection. ANZ Nuclear Medicine 41: 24-32. Link: https://bit.ly/2VoIMqc

23. Fleming RM, Harrington GM, Baqir R, Jay S, Challapalli S, et al. (2011) Renewed Application of an Old Method Improves Detection of Coronary Ischemia. A Higher Standard of Care. Gamma Gazette 1: 50-58. Link: https://bit.ly/2JT7T7X

24. Fleming RM, Harrington GM, Jay S, Avery K (2011) FHRWW Rest SPECT Viability Imaging-Cardiac viability measured using resting FHRWW Redistribution of Sestamibi: The Scientific Evidence proves "Sestamibi is not Superglue." ANZ Nuc Med.

25. Fleming RM, Harrington GM (2011) Quantitative measurement of sestamib redistribution to detect hidden ischemia made possible by application of Blumgart's method. J Nucl Med 52: 1162. Link: https://bit.ly/39Vz1gV

26. Fleming RM, Harrington GM, Kearney DS, Tomsho M, Sheils J (2012) Myoview and Sestamibi redistribution, stress once - image twice protocol improves detection of ischemia in addition to improving patient throughput and reducing patient radiation to $3.75 \mathrm{mSv}$. J Nucl Med 53: 1831. Link: https://bit.ly/2y2yxsm

27. Fleming RM, Fleming MR, Chaudhuri T, McKusick A, Dooley WC et al. (2018) Both percent diameter stenosis (\%DS) and coronary flow reserve can be derived directly from myocardial perfusion imaging using FMTVDM and measurement of isotope redistribution. J Nucl Med Radiat Ther 9: 353. Link: https://bit.ly/3eg3bP

28. Fleming RM, Fleming MR, Dooley WC, Sheikh A, McKusick A, et al. (2018) FMTVDM - FHRWW \& B.E.S.T. The FIRST TRUE "Quantitative" Nuclear Imaging Protocols with Proprietary Equations following The Fleming Method (TFM) for Nuclear Scintillation Equipment Quantitative Standardization. Biomed J Sci Tech Res 4: 1-4. Link: https://bit.ly/34rrIN3

29. Fleming RM, Fleming MR, McKusick A, Chaudhuri T (2018) FMTVDM-TFM@® True Quantification requires Standardization of the tool being used to Measure, with a Known, Unchanging Standard to produce accurate, consistent and reproducible Quantified Measurements. J Nucl Cardiol 26: 1780-1783. Link: https://bit.ly/3aVYQyR

30. Fleming RM, Fleming MR, Harrington G, McKusick A, Chaudhuri T (2018) USVAH Study demonstrates statistically significant improvement in diagnosis and care of U.S. Veterans using FMTVDM-FHRWW (C) "Quantitative" Nuclear Imaging. The era of truly quantitative stress-first, stress-only imaging has begun!. J Nucl Med Radiat Ther S9: 6. Link: https://bit.ly/39XHbW3

31. Fleming RM, Fleming MR, McKusick A, Chaudhuri T (2018) Multi Center Clinical Trial Confirms FMTVDM@® MPI in Seven Modern Clinical Laboratories in the U.S.A. and Asia. Artificial Intelligence (AI) with True Quantification. J Nucl Med Radiat Ther 9: 372. Link: https://bit.ly/2wwOFSv

32. Fleming RM, Fleming MR, Chaudhuri TK, McKusick A (2019) Proposed Acute Coronary Syndrome (ACS) Chest Pain Pathway Using Quantitative FMTVDM Nuclear Imaging. Adv Can Res Clinical Imag 1: 1-2. Link: https://bit.ly/3ecqXf3

33. Fleming RM, Fleming MR, Chaudhuri TK, Dooley WC (2019) Simultaneous Quantitative Cardio Oncology Imaging Now Possible Using FMTVDM. Biomed J Sci Tech Res 20: 15138-15143. Link: https://bit.ly/2ySjQZg

Citation: Fleming RM, Fleming MR (2020) FMTVDM-Finally Opens the Doorway from Qualitative to Quantitative Measurement and Treatment of Heart Disease. $J$ Cardiovasc Med Cardiol 7(2): 060-062. DOI: https://dx.doi.org/10.17352/2455-2976.000114 
34. Fleming RM, Fleming MR, Chaudhuri TK, McKusick A (2019) Machine Learning through FMTVDM Proprietary QCA Equations. J Angiol Vasc Surg 4: 026. Link: https://bit.ly/3aOXQYM

35. Fleming RM, Fleming MR, Chaudhuri TK, McKusick A (2019) First Patented Quantitative Molecular Imaging Method for Detection and Measurement of CAD and Cancer. ACTA Scientific Pharm Sci 3: 30-32. Link: https://bit.ly/2JVo9p1

36. Fleming RM, Fleming MR, Chaudhuri TK, McKusick A (2019) FMTVDM Quantitative Imaging Replaces Current Qualitative Imaging for Coronary Artery Disease and Cancer, Increasing Diagnostic Accuracy and Providing PatientSpecific, Patient-Directed Treatment. Cardio Open 4: 1-2. Link: https://bit ly/2XtLMwz

37. Fleming RM, Fleming MR, Chaudhuri TK, Harrington GM (2019) Redistribution Measurement: A New (Old) Tool for Finding Heart Disease? Acta Scientific Pharm Sci 3: 25-28

38. Fleming RM, Fleming MR, Chaudhuri TK, Dooley WC (2019) Part I: Proposed New Standards of Care for the Work up of Chest Pain and Breast Lumps. J Emer Med Prim Care 2: 1-3. Link: https://bit.ly/2RKOXhR

39. Fleming RM, Fleming MR, Chaudhuri TK, Dooley WC (2019) Part II: Proposed New Standards of Care for the Work up of Chest Pain and Breast Lumps. J Emer Med Prim Care 2: 4-6. Link: https://bit.ly/2V2gbAO

40. Fleming RM, Fleming MR, Chaudhuri TK (2019) Myocardial Perfusion Imaging
Measurements with FMTVDM Unmask Critial CAD. Acta Scientific Pharm Sci 1-2. Link: https://bit.ly/2RuJUQr

41. Fleming RM, Harrington GM, Baqir R (2008) Using Multiple Images Post-stress to Enhance Diagnostic Accuracy of Myocardial Perfusion Imaging: The Clinical Importance of Determining Washin \& Washout Indicates a Parabolic Function Between Coronary Perfusion (Blood Flow) and Cellular ("Uptake/Release) Function. (submitted by "invitation only" to Nova Science March 2008, Heart Disease in Men.

42. Fleming RM, Harrington GM, Baqir R (2009) Heart Disease in Men. Chapter 3. Using Multiple Images Post-Stress to Enhance diagnostic Accuracy of Myocardial Perfusion Imaging: The Clinical Importance of Determining Washin and Washout Indicates a Parabolic Function between Coronary Perfusion (Blood Flow) and Cellular ("Uptake/Release") Function. Alice B. Todd and Margo H. Mosley Editors, Nova Publishers 75-100. Link: https://bit.ly/34q3jYc

43. Fleming RM, Harrington GM (2011) Chapter 13. Fleming Harrington Redistribution Wash-in Washout (FHRWW): The Platinum Standard for Nuclear Cardiology. Establishing Better Standards of Care in Doppler Echocardiography, Computed Tomography and Nuclear Cardiology. Richard M. Fleming, Editor, Intech Publishing. Link: https://bit.ly/2Rx6DeW

44. (2019) FMTVDM: The Fleming Method for Tissue and Vascular Differentiation and Metabolism Using Same State Single or Sequential Quantification Comparisons. Evidence Based Medicine. Link: https://bit.ly/3b2eUPw

\section{Discover a bigger Impact and Visibility of your article publication with} Peertechz Publications

\section{Highlights}

* Signatory publisher of ORCID

- Signatory Publisher of DORA (San Francisco Declaration on Research Assessment)

* Articles archived in worlds' renowned service providers such as Portico, CNKI, AGRIS, TDNet, Base (Bielefeld University Library), CrossRef, Scilit, J-Gate etc.

* Journals indexed in ICMJE, SHERPA/ROMEO, Google Scholar etc.

* OAI-PMH (Open Archives Initiative Protocol for Metadata Harvesting)

* Dedicated Editorial Board for every journal

* Accurate and rapid peer-review process

* Increased citations of published articles through promotions

* Reduced timeline for article publication

Submit your articles and experience a new surge in publication services (https://www.peertechz.com/submission).

Peertechz journals wishes everlasting success in your every endeavours.

Copyright: (c) 2020 Fleming RM, et al. This is an open-access article distributed under the terms of the Creative Commons Attribution License, which permits unrestricted use, distribution, and reproduction in any medium, provided the original author and source are credited.

Citation: Fleming RM, Fleming MR (2020) FMTVDM-Finally Opens the Doorway from Qualitative to Quantitative Measurement and Treatment of Heart Disease. J Cardiovasc Med Cardiol 7(2): 060-062. DOI: https://dx.doi.org/10.17352/2455-2976.000114 